\title{
PENGARUH UMR DAN PENDIDIKAN TERHADAP KESEMPATAN KERJA DAN PERTUMBUHAN EKONOMI KABUPATEN/KOTA PROVINSI BALI
}

\section{Wayan Gunawan' ${ }^{1}$ Sudarsana Arka ${ }^{2}$}

Article history:

Submitted: 8 Maret 2021

Revised: 12 Maret 2021

Accepted: 22 Maret 2021

Keywords:

Wages;

Education;

Economic growth;
Kata Kunci:

Upah;

Pendidikan;

Pertumbuhan ekonomi;

\section{Koresponding: \\ FakultasEkonomi dan Bisnis, \\ Universitas Udanyana, \\ Denpasar, Bali. \\ Email : \\ gunawansocial16@gmail.com}

Abstract

The purpose of this research is to analyze the influence of UMR and education on job opportunities in regencies/cities of Bali Province, to analyze the influence of UMR, education and job opportunities on economic growth in districts / cities of Bali Province, and to analyze the role of job opportunities to mediate the influence of UMR and education. on economic growth in the regencies/cities of Bali Province. The data used in this research is secondary data. This study uses panel data with a total of 45 observations using non-participant observation methods of data collection. The analysis technique used in this research is path analysis. The results showed that the UMR did not have a significant effect on job opportunities in districts / cities in Bali Province, while education had a positive and significant effect on job opportunities in districts / cities in Bali Province. The UMR has a negative and significant effect on economic growth in districts / cities in Bali Province, while education and job opportunities have a positive and significant effect on economic growth in districts/ cities in Bali Province. Job opportunities do not mediate the effect of the UMR on economic growth in districts / cities in Bali Province. Meanwhile, job opportunities mediate the effect of education on economic growth in districts / cities in Bali Province.

Abstrak
Penelitian ini bertujuan untuk menganalisis pengaruh UMR dan
pendidikan terhadap kesempatan kerja di kabupaten/kota Provinsi Bali,
untuk menganalisis pengaruh UMR, pendidikan dan kesempatan kerja
terhadap pertumbuhan ekonomi di kabupaten/kota Provinsi Bali, dan untuk
menganalisis peran kesempatan kerja memediasi pengaruh UMR dan
pendidikan terhadap pertumbuhan ekonomi di kabupaten/kota Provinsi
Bali. Data yang dipergunakan dalam penelitian ini adalah data sekunder.
Penelitian ini menggunakan data panel dengan jumlah pengamatan
sebanyak 45 dengan menggunakan metode pengumpulan data secara
observasi non partisipan. Teknik analisis yang digunakan dalam penelitian
ini adalah analisis jalur (path analysis). Hasil penelitian menunjukkan
bahwa UMR tidak berpengaruh signifikan terhadap kesempatan kerja di
kabupaten/kota di Provinsi Bali, sedangkan pendidikan berpengaruh positif
dan signifikan terhadap kesempatan kerja di kabupaten/kota di Provinsi
Bali. UMR berpengaruh negatif dan signifikan terhadap pertumbuhan
ekonomi di kabupaten/kota di Provinsi Bali, sedangkan pendidikan dan
kesempatan kerja berpengaruh positif dan signifikan terhadap pertumbuhan
ekonomi di kabupaten/kota di Provinsi Bali. Kesempatan kerja tidak
memediasi pengaruh UMR terhadap pertumbuhan ekonomi di
kabupaten/kota di Provinsi Bali. Sedangkan Kesempatan kerja memediasi
pengaruh pendidikan terhadap pertumbuhan ekonomi di kabupaten/kota di
Provinsi Bali.
pengaruh pen
Provinsi Bali

Fakultas Ekonomi dan Bisnis, Universitas Udayana, Denpasar, Bali ${ }^{2}$

Email: gunawansocial16@gmail.com ${ }^{2}$ 


\section{PENDAHULUAN}

Indonesia sebagai negara berkembang dengan jumlah penduduk terbesar ke empat di dunia memiliki potensi pasar yang cukup besar dilihat dari sisi input tenaga kerja. Jumlah penduduk yang besar dapat menjadi penggerak perekonomian dari sisi penawaran (Erick, 2016). Namun kenyataannya yang dihadapi hingga saat ini, jumlah penduduk dan tenaga kerja yang besar tidak menjadi aset potensial yang dapat dikembangkan untuk mendorong kegiatan ekonomi melainkan secara tidak langsung menjadi beban negara dalam pembangunan (Hung \& Shengquan, 2014). Salah satu masalah yang cukup serius dihadapi Indonesia adalah masalah pertumbuhan ekonomi, pertumbuhan ekonomi adalah keadaan di mana terjadi perkembangan kegiatan dalam perekonomian yang ditandai dengan meningkatnya produksi barang dan jasa dan meningkatnya kemakmuran masyarakat (Izatun, 2015).

Pertumbuhan ekonomi menunjukkan adanya kegiatan dalam perekonomian yang menyebabkan peningkatan produksi barang dan jasa yang dihasilkan oleh masyarakat dan diikuti oleh peningkatan kemakmuran masyarakat yang biasanya dilihat dari pendapatan domestik regional bruto (Oka \& Sudarsana, 2015). Pertumbuhan ekonomi suatu negara atau suatu wilayah yang terus menunjukkan peningkatan menggambarkan bahwa perekonomian negara atau wilayah tersebut berkembang dengan baik (Sudarsono, 1995). Pertumbuhan ekonomi telah lama dijadikan sebagai indikator keberhasilan pembangunan ekonomi dalam mengatasi pertumbuhan penduduk (Sukirno, 2007).

Tabel 1.

Laju Pertumbuhan Ekonomi di Kabupaten/Kota Provinsi Bali, 2013-2017

\begin{tabular}{lccccc}
\hline \multirow{2}{*}{$\begin{array}{c}\text { Kabupaten/Kota } \\
\text { di Provinsi Bali }\end{array}$} & \multicolumn{3}{c}{$\begin{array}{c}\text { Pertumbuhan Ekonomi } \\
\text { (persen) }\end{array}$} \\
\cline { 2 - 6 } & $\mathbf{2 0 1 3}$ & $\mathbf{2 0 1 4}$ & $\mathbf{2 0 1 5}$ & $\mathbf{2 0 1 6}$ & $\mathbf{2 0 1 7}$ \\
\hline Jembrana & 5,69 & 6,05 & 6,19 & 5,96 & 5,31 \\
Tabanan & 6,45 & 6,53 & 6,19 & 6,14 & 5,38 \\
Badung & 6,82 & 6,98 & 6,24 & 6,81 & 6,11 \\
Gianyar & 6,82 & 6,80 & 6,30 & 6,31 & 5,50 \\
Klungkung & 6,05 & 5,98 & 6,11 & 6,28 & 5,34 \\
Bangli & 5,94 & 5,83 & 6,16 & 6,24 & 5,35 \\
Karangasem & 6,16 & 6,01 & 6,00 & 5,92 & 5,08 \\
Buleleng & 7,15 & 6,96 & 6,07 & 6,02 & 5,40 \\
Kota Denpasar & 6.96 & 7,00 & 6,14 & 6,51 & 6,08 \\
\hline Provinsi Bali & $\mathbf{6 , 6 9}$ & $\mathbf{6 , 7 3}$ & $\mathbf{6 , 0 3}$ & $\mathbf{6 , 3 2}$ & $\mathbf{5 , 5 9}$ \\
\hline Sumber: BPS Provinyyyyyyyyy
\end{tabular}

Sumber: BPS Provinsi Bali, 2019

Laju pertumbuhan ekonomi di kabupaten/kota yang ada di Bali dari tahun 2013 hingga 2017 mengalami fluktuatif. Hal senada juga terjadi pada pertumbuhan ekonomi di Provinsi Bali dari tahun 2013 sampai 2017 mengalami fluktuasi, pertumbuhan ekonomi tertinggi dalam rentang waktu 5 tahun tersebut terdapat ditahun 2014 sebesar 6.73 persen, yang mengalami peningkatan sebesar 0.04

Pengaruh UMR dan Pendidikan Terhadap Kesempatan Kerja dan Pertumbuhan Ekonomi Kabupaten/Kota 
persen dari tahun sebelumnya, sedangkan pertumbuhan ekonomi rendah/mengalami penurunan yaitu ditahun 2017 yaitu sebesar 5.59 persen atau mengalami penurunan sebesar 0.73 persen dari tahun sebelumnya. Menurut penelitian Suartha \& Murjana (2017), yang menyatakan bahwa peningkatan/penurunan pertumbuhan ekonomi tersebut dikarenakan oleh kondisi ekonomi wilayah seperti inflasi, deflasi, peranan masing-masing sektor ekonomi, dan tingkat daya beli masyarakat bali pada umumnya.

Beberapa kebijakan yang telah ditempuh oleh pemerintah Provinsi Bali untuk mengatasi pertumbuhan ekonomi, salah satunya dengan mendorong kesempatan kerja agar dapat menciptakan kesejahteraan masyarakat (Samuel, 2017). Hal ini sesuai dengan apa yang dikemukakan oleh Vivi \& Lisa (2016) dalam teorinya yang berjudul derive demand theory, yang mengatakan adanya peningkatan permintaan output didalam suatu perusahaan, akan mendorong permintaaan akan tenaga kerja dan mampu meningkatkan pertumbuhan ekonomi (Ximena et al., 2013). Laju pertumbuhan penduduk yang cukup tinggi, tidak diimbangi dengan adanya kesempatan kerja (Mantra, 2009). Kesempatan kerja merupakan suatu keadaan yang menggambarkan ketersediaan pekerjaan untuk diisi oleh para pencari kerja (Samuel, 2017). Namun bisa diartikan juga sebagai permintaan atas tenaga kerja. Dapat dikatakan kesempatan kerja adalah suatu peluang yang harus diperjuangkan oleh para pencari kerja agar mereka dapat memperoleh pekerjaan dan hidup dengan layak serta mensejahterakan diri dan keluarganya (Syahril, 2014).

Kesempatan kerja dapat dijelaskan dari dua sudut pandang, yaitu dari teori klasik dan teori Keynes (Ade \& Rizky, 2015). Mudrajad (2013) Teori klasik mengemukakan pandangan mengenai kesempatan kerja, yaitu bahwa tingkat output dan harga keseimbangan hanya bisa dicapai kalau perekonomian berada pada tingkat kesempatan kerja penuh (full employment). Sementara, keseimbangan dengan tingkat kesempatan kerja penuh (equilibrium with full employment) hanya bisa dicapai melalui bekerjanya mekanisme pasar bebas. Jadi, adanya mekanisme pasar yang bekerja secara bebas tanpa campur tangan pemerintah itu merupakan syarat untuk tercapainya keseimbangan dengan kesempatan kerja penuh. Keseimbangan dengan kesempatan kerja penuh tersebut menurut kaum klasik merupakan kondisi yang ideal atau normal dari suatu perekonomian (Richard \& Robert, 2017). Jika sampai terjadi pengangguran di dalam perekonomian, maka hal tersebut hanyalah gejala atau fenomena yang bersifat sementara, bahwa dalam jangka panjang akan hilang dengan sendirinya melalui bekerjanya secara bebas mekanisme pasar.

Berbeda halnya dari pandangan Keynes, kesempatan kerja menurut pandangan Keynes, berbeda dengan klasik. Menurut Keynes, kegiatan perekonomian tergantung pada segi permintaan, yaitu tergantung kepada perbelanjaan atau pengeluaran agregat yang dilakukan perekonomian pada suatu waktu tertentu. Pengeluaran agregat diartikan sebagai pengeluaran yang dilakukan untuk

Pengaruh UMR dan Pendidikan Terhadap Kesempatan Kerja dan Pertumbuhan Ekonomi Kabupaten/Kota 
membeli barang dan jasa yang dihasilkan oleh sesuatu perekonomian dalam suatu periode tertentu, dan hanya bisa diukur untuk suatu tahun tertentu (Saltiel, 2017). Simpulan dari beberapa penelitian, seperti Patricia (2017) menyatakan kesempatan kerja memiliki pengaruh positif terhadap pertumbuhan ekonomi. Syahrina \& Abdul (2015) menyatakan dalam penelitiannya kesempatan kerja memiliki pengaruh positif terhadap pertumbuhan ekonomi. Dipertegas oleh Emilia (2015) kesempatan kerja memberikan pengaruh positif untuk pertumbuhan ekonomi.

Menurut Atiyatna dkk, (2016) yang menyatakan bahwa upah minimum regional (UMR) berpengaruh positif terhadap kesempatan kerja. Upah minimum regional yang diterima buruh harus cukup untuk memenuhi kebutuhan pekerja dan keluarganya dengan wajar (Siti \& Hashim, 2016). Salah satu unsur yang menentukan kemakmuran suatu masyarakat adalah tingkat upah yang seimbang. Upah minimum regional adalah pendapatan masyarakat yang mencapai maksimum apabila kondisi tingkat penggunaan tenaga kerja penuh (full employment) dapat terwujud (Aleksandra \& Zbigniew, 2014).

Teori dana upah yang dikemukakan oleh John Stuart Mill, mengatakan bahwa tinggi upah tergantung kepada permintaan dan penawaran tenaga kerja. Sedangkan penawaran tenaga kerja tergantung pada jumlah dana upah yaitu jumlah modal yang disediakan perusahaan untuk pembayaran upah. Peningkatan jumlah penduduk akan mendorong tingkat upah yang cenderung turun, karena tidak sebanding antara jumlah tenaga kerja dengan penawaran tenaga kerja (Suarta et al., 2017). Teori klasik juga menjelaskan bahwa cara mengatasi pertumbuhan penduduk dengan kesempatan tenaga kerja adalah dengan mengurangi tingkat upah minimum regional. Teori klasik menganggap bahwa jika upah turun maka permintaan pasar akan tenaga kerja akan meningkat.

Menurut Dian et al., (2015), faktor lain yang juga mempengaruhi pertumbuhan ekonomi dan kesempatan kerja adalah pendidikan, bagi individu yang bisa melanjutkan pendidikan ke perguruan tinggi pada umumnya didasari harapan adanya peluang kerja dan pengembangan karier yang lebih terbuka pada masa mendatang. Adanya kenyataan peluang mendapatkan pekerjaan yang semakin sulit akibat kebijakan ekonomi politik negara yang belum berpihak pada terbukanya lapangan pekerjaan yang seluas-luasnya bagi rakyat menjadikan tidak adanya jaminan bagi tamatan perguruan tinggi memiliki kemudahan dalam mendapatkan pekerjaan. Kondisi ini berpotensi dalam memunculkan kecemasan akan kesulitan lapangan pekerjaan pada setiap individu (Izatun, 2015).

Sharon \& Joseph (2018) meyatakan pendidikan merupakan proses pengubahan sikap dan perilaku seseorang atau sekelompok orang dalam usaha mendewasakan manusia melalui upaya pengajaran dan pelatihan. Menurut Dian et al. (2015) Pendidikan merupakan salah satu faktor yang penting dalam pengembangan sumber daya manusia (SDM). Pendidikan tidak hanya menambah pengetahuan, akan tetapi juga meningkatkan keterampilan bekerja, dengan demikian meningkatkan

Pengaruh UMR dan Pendidikan Terhadap Kesempatan Kerja dan Pertumbuhan Ekonomi Kabupaten/Kota 
produktivitas kerja. Pendidikan dipandang sebagai investasi yang imbalannya dapat diperoteh beberapa tahun kemudian dalam bentuk pertambahan hasil kerja. Ilmu dan teknologi yang diberikan di lembaga pendidikan apabila dikuasai oleh lulusannya akan menjadi modal sebagai tenaga kerja produktif dan akhirnya akan meningkatkan ekonomi (Izatun, 2015).

Fenomena susahnya orang berpendidikan tinggi mendapatkan pekerjaan di negerinya sendiri tentu dengan gaji yang layak) itu bukan menjadi monopoli khas Indonesia. Harap diingat di Negara-negara padat penduduk seperti India, Pakistan, Iran, Mesir atau China misalnya kejadian yang sama juga mereka alami (Dian et al., 2015). Betapa banyak lulusan perguruan tinggi dari negara yang disebutkan di atas terpaksa bekerja mengadu nasib di luar negeri karena di negaranya tidak ada lowongan yang memadai. Suatu bangsa harus meningkatkan investasi bidang pendidikan untuk mencapai tujuan tersebut, maka dari itu pendidikan sangat berperan penting dalam meningkatkan kualitas manusia disuatu bangsa (Izatun, 2015). Suatu bangsa harus meningkatkan investasi bidang pendidikan dan investasi bidang kesehatan untuk mencapai tujuan tersebut, maka dari itu pendidikan sangat berperan penting dalam meningkatkan kualitas manusia disuatu Negara (Meier, et al, 2005). Dapat kita simpulkan bahwa pendidikan penduduk di Kabupaten/Kota di Provinsi Bali semakin mengalami peningkatan, dalam hal ini berarti dengan meningkatnya pendidikan yang ada maka kualitas tenaga kerja yang ada di Provinsi Bali semakin bagus.

Beberapa penelitian seperti Izatun (2015) menyatakan pendidikan memiliki pengaruh positif terhadap kesempatan kerja. Dian et al. (2015) menyatakan dalam penelitiannya pendidikan memiliki pengaruh positif terhadap kesempatan kerja. Dipertegas oleh Sharon \& Joseph (2018) pendidikan memberikan pengaruh positif untuk kesempatan kerja. Penelitian Sharon \& Joseph (2018) pendidikan tidak memiliki pengaruh positif terhadap kesempatan kerja. Penelitian lainnya juga menyatakan hubungan mediasi antara pengaruh UMR dan pendidikan terhadap kesempatan kerja dan pertumbuhan ekonomi yaitu penelitian Gideon et al., (2013) kesempatan kerja mampu memediasi pengaruh UMR terhadap pertumbuhan ekonomi. Keiko (2015) memberikan pernyataan yang sama bahwa kesempatan kerja memediasi pengaruh UMR dan pendidikan terhadap pertumbuhan ekonomi. Kiran et al. (2014) membuktikan hal yang sama bahwa kesempatan kerja memediasi pengaruh UMR dan pendidikan terhadap pertumbuhan ekonomi.

Berdasarkan uraian di atas, dengan melihat adanya keterkaitan antara pertumbuhan ekonomi, UMR, tingkat pendidikan dan kesempatan kerja sesuai dengan apa yang dinyatakan pada penelitian sebelumnya, maka dari itu penelitian ini bertujuan untuk menganalisis pengaruh UMR dan pendidikan terhadap kesempatan kerja di kabupaten/kota Provinsi Bali, untuk menganalisis pengaruh UMR, pendidikan dan kesempatan kerja terhadap pertumbuhan ekonomi di kabupaten/kota Provinsi 
Bali, dan untuk menganalisis peran kesempatan kerja memediasi pengaruh UMR dan pendidikan terhadap pertumbuhan ekonomi di kabupaten/kota Provinsi Bali.

\section{METODE PENELITIAN}

Penelitian ini dilakukan di Provinsi Bali yang terdiri atas 8 kabupaten dan 1 kota, penelitian ini menggunakan data-data sekunder yang publikasi oleh Badan Pusat Statistik, Dinas Ketenagakerjaan, Badan Penanaman Modal dan Perizinan, yang terkait dengan obyek penelitian. Variabel eksogen dalam penelitian ini adalah adalah UMR $\left(\mathrm{X}_{1}\right)$ dan pendidikan $\left(\mathrm{X}_{2}\right)$. UMR $\left(\mathrm{X}_{1}\right)$ dalam penelitian ini adalah upah bulanan yang terdiri dari upah pokok dan tunjangan tetap bagi seorang pekerja tingkat paling bawah dan bermasa kerja kurang dari satu tahun yang berlaku di suatu daerah tertentu, upah mempunyai kedudukan yang strategis bagi tenaga kerja, perusahaan dan bagi pemerintah (Simanjuntak, 2015). Dalam penelitian ini UMR menggunakan data UMR tingkat kabupaten/kota di Provinsi Bali yang dipublikasi oleh BPS Provinsi Bali dari tahun 2013-2017 dalam satuan rupiah.

Pendidikan $\left(\mathrm{X}_{2}\right)$, merupakan salah satu faktor yang penting dalam pengembangan sumber daya manusia (SDM). Pendidikan tidak hanya menambah pengetahuan, akan tetapi juga meningkatkan keterampilan bekerja, dengan demikian meningkatkan produktivitas kerja (Harsono 2011). Pendidikan dalam penelitian ini menggunakan data rata-rata lama sekolah penduduk di tingkat kabupaten/kota di Provinsi Bali dari tahun 2013-2017, yang dipublikasi dari Badan Pusat Statistik Provinsi Bali dalam satuan tahun.

Variabel mediasi yang diguankan dalam penelitian ini adalah kesempatan kerja $\left(\mathrm{Y}_{1}\right)$. Kesempatan kerja secara umum diartikan sebagai suatu keadaan yang mencerminkan jumlah dari total angkatan kerja yang dapat diserap atau ikut serta aktif dalam kegiatan perekonomian (Sukirno 2007). Dalam penelitian ini kesempatan kerja menggunakan data jumlah kesempatan kerja di tingkat kabupaten/kota di Provinsi Bali yang di publikasi oleh BPS Provinsi Bali dari tahun 2013-2017 dalam satuan orang.

Variabel endogen dalam penelitian ini adalah pertumbuhan ekonomi ( $\left.\mathrm{Y}_{2}\right)$. Menurut Sukirno (2007) adalah sebagian dari perkembangan kesejahteraan masyarakat yang diukur dengan besarnya pertumbuhan produk domestik regional bruto per kapita (PDRB per kapita). Dalam penelitian ini pertumbuhan ekonomi menggunakan data PDRB per kapita menurut kabupaten/kota di Bali yang diperoleh dari Badan Pusat Statistik Provinsi Bali dari tahun 2013 sampai 2017 dalam satuan persen.

Pengaruh UMR dan Pendidikan Terhadap Kesempatan Kerja dan Pertumbuhan Ekonomi Kabupaten/Kota 
Sumber data yang dipergunakan dalam penelitian ini adalah sumber data sekunder. Data sekunder merupakan data yang sudah diolah dan diperoleh dalam bentuk jadi yang dikumpulkan dan diperoleh secara tidak langsung melalui media perantara. Data sekunder dalam penelitian ini adalah data tingkat pendidikan, UMR, kesempatan kerja dan data pertumbuhan ekonomi dari 8 Kabupaten dan 1 Kota yang diperolah dari Badan Pusat Statistik Provinsi Bali dari tahun 2013-2017. Penelitian ini menggunakan data panel yang terdiri atas data time series dan cross section. Data time series yang digunakan berupa data tahunan selama 5 tahun dari tahun 2013 sampai tahun 2017, sedangkan data cross section berupa dari data 9 kabupaten/kota, sehingga jumlah pengamatan sebanyak 5 x $9=45$. Teknik analisis data yang digunakan dalam penelitian ini adalah metode analisis jalur (Path Analysis). Analisis jalur merupakan perluasan dari analisis regresi linier berganda, untuk menaksir hubungan kausalitas antar variabel ditunjukkan oleh anak panah. Analisis ini digunakan untuk mengetahui hubungan langsung variabel independen terhadap variabel dependen dan hubungan tidak langsung melalui variabel mediasi (Suyana, 2016: 159).

\section{HASIL DAN PEMBAHASAN}

Berdasarkan hasil penelitian dapat diketahui hubungan antar variabel penelitian yang ditunjukkan oleh koefisien jalur dalam penelitian ini. Koefisien jalur dapat dibuat dalam bentuk diagram jalur (Suyana, 2016).

Tabel 3.

Hasil Analisis Regresi Persamaan Struktural 1

\begin{tabular}{|c|c|c|c|c|c|c|}
\hline \multicolumn{7}{|c|}{ Coefficients $^{\mathrm{a}}$} \\
\hline \multirow[b]{2}{*}{ Model } & & \multicolumn{2}{|c|}{ Unstandardized Coefficients } & $\begin{array}{l}\text { Standardized } \\
\text { Coefficients }\end{array}$ & & \multirow[b]{2}{*}{ Sig. } \\
\hline & & B & Std. Error & Beta & $\mathrm{t}$ & \\
\hline \multirow[t]{3}{*}{1} & (Constant) & 9.690 & 4.571 & & 2.120 & .040 \\
\hline & UMR & -.018 & .331 & -.007 & -.053 & .958 \\
\hline & Pendidikan & 1.414 & .313 & .595 & 4.519 & .000 \\
\hline \multicolumn{7}{|c|}{ a. Dependent Variable: Kesempatan Kerja } \\
\hline \multicolumn{7}{|c|}{ Sumber : Hasil olahan data, 2020} \\
\hline
\end{tabular}

Keragaman data yang dapat dijelaskan oleh model adalah sebesar 0,77 atau dengan kata lain informasi yang terkandung dalam data sebesar 77,0 persen yang dapat dijelaskan oleh model, dan sisanya sebesar 23.0 persen dijelaskan oleh variabel lain yang tidak terdapat dalam model.

Pengaruh UMR dan Pendidikan Terhadap Kesempatan Kerja dan Pertumbuhan Ekonomi Kabupaten/Kota 
Tabel 4.

Hasil Analisis Regresi Persamaan Struktural 2

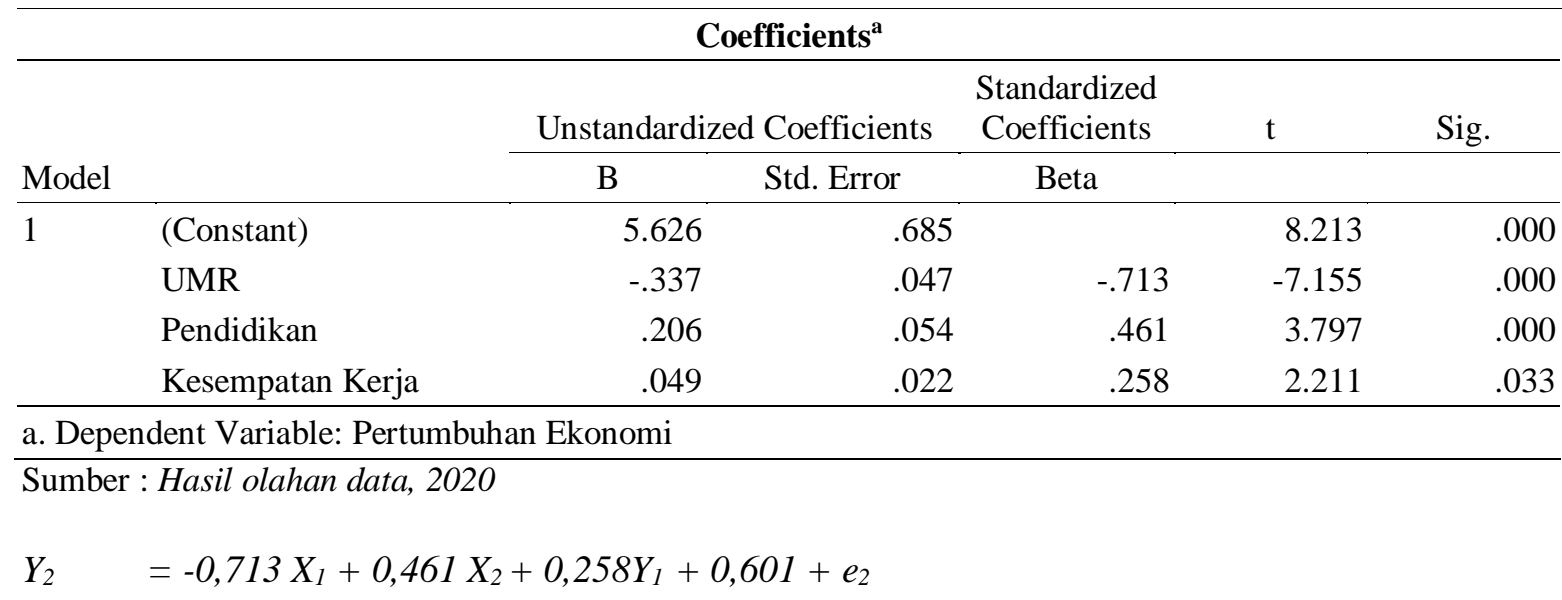

Uji kelayakan model atau yang sering disebut dengan uji $\mathrm{F}$ merupakan tahapan awal untuk mengidentifikasi model regresi yang diestimasi layak atau tidak.

Tabel 5.

Hasil Uji Kelayakan Model Struktur 1

\begin{tabular}{llrrrrr}
\hline \multicolumn{7}{c}{ ANOVA $^{\mathbf{b}}$} \\
\hline Model & & Sum of Squares & df & Mean Square & F & Sig. \\
\hline 1 & Regression & 2.844 & 2 & 1.422 & 11.394 & $.000^{\text {a }}$ \\
& Residual & 5.242 & 42 & .125 & & \\
& Total & 8.085 & 42 & & & \\
\hline
\end{tabular}

a. Predictors: (Constant), Pendidikan, UMR

b. Dependent Variable: Kesempatan Kerja

Sumber : Hasil olahan data, 2020

Nilai signifikan sebesar 0,000 yang lebih kecil dari $\alpha=0,05$ maka model yang digunakan pada penilitian ini adalah layak. Hasil ini memberikan makna bahwa UMR dan pendidikan mampu memprediksi atau menjelaskan kesempatan kerja.

Tabel 6.

Hasil Uji Kelayakan Model Struktur 2

\begin{tabular}{|c|c|c|c|c|c|c|}
\hline \multicolumn{7}{|c|}{ ANOVA $^{b}$} \\
\hline Model & & Sum of Squares & $\mathrm{df}$ & Mean Square & $\mathrm{F}$ & Sig. \\
\hline \multirow[t]{3}{*}{1} & Regression & .183 & 3 & .061 & 24.141 & $.000^{\mathrm{a}}$ \\
\hline & Residual & .104 & 41 & .003 & & \\
\hline & Total & .287 & 44 & & & \\
\hline
\end{tabular}

a. Predictors: (Constant), Kesempatan kerja, UMR, Pendidikan

b. Dependent Variable: Pert. Ekonomi

Sumber : Hasil olahan data, 2020

Nilai signifikan sebesar 0,000 yang lebih kecil dari $\alpha=0,05$ maka model yang digunakan pada penilitian ini adalah layak. Hasil ini memberikan makna bahwa UMR, pendidikan dan Pengaruh UMR dan Pendidikan Terhadap Kesempatan Kerja dan Pertumbuhan Ekonomi Kabupaten/Kota 
kesempatan kerja mampu menjelaskan pertumbuhan ekonomi. Berdasarkan hasil analisis diperoleh standardized coefficients Beta sebesar -0,007 dengan nilai signifkansi 0,958> $\alpha=0,05$, maka dapat disimpulkan bahwa UMR tidak berpengaruh terhadap kesempatan kerja di Kabupaten dan Kota Provinsi Bali. Hal tersebut berarti bahwa ketika terjadi peningkatan UMR tidak berpengaruh terhadap banyaknya jumlah ketersediaan kesempatan kerja yang ada di tingkat kabupaten/kota yang ada di Provinsi Bali. Dapat diketahui bahwa UMR atau upah minimum regional merupakan standar upah yang dapat diperoleh oleh pekerja pada suatu wilayah yang ditentukan berdasarkan kondisi perekonomian wilayah, semakin baik kondisi ekonomi wilayah maka jumlah UMR yang dapat diterima akan semakin meningkat, begitu sebaliknya jika ekonomi wilayah berjalan lamban/buruk, maka UMR yang akan diterima oleh pekerja akan semakin kecil dan cenderung menimbulkan disparitas upah antar wilayah yang ada.

Menurut penelitian Suharto \& Ridwan (2016), yang menyatakan bahwa peningkatan upah minimum regional tidak berpengaruh signifikan terhadap penyerapan kesempatan kerja, hal tersebut dikarenakan bahwa ketika terjadi peningkatan upah maka perusahaan akan cenderung mengurangi jumlah pekerjanya karena diiringi dengan produksi yang dihasilkan tetap sama dan bahkan cenderung menurun karena faktor lebih besar biaya produksi yang dikeluarkan dari pada hasil yang diterima. Hal senada juga diungkapkan oleh penelitian Wihastuti \& Henny (2018) yang menyatakan bahwa UMR tidak berpengaruh signifikan terhadap penyerapan tenaga kerja, hal tersebut dikarenakan bahwa UMP dapat menyebabkan suatu kondisi penurunan penyerapan tenaga kerja akibat dari kurang sebandingnya antara pertumbuhan tenaga kerja (yaitu jumlah angkatan kerja yang terus bertambah) dengan kapasitas dunia usaha dalam melakukan penyerapan tenaga kerja.

Berdasarkan hasil analisis diperoleh standardized coefficients Beta sebesar 0,595 dengan nilai signifkansi $0,000<\alpha=0,05$, dapat diketahui bahwa pendidikan berpengaruh positif dan signifikan terhadap kesempatan kerja yang ada di wilayah Kabupaten dan Kota di Provinsi Bali. Hal tersebut berarti bahwa ketika tingkat pendidikan seseorang/pekerja semakin tinggi mencapai tingkat pendidikan kejenjang perguruan tinggi, maka kesempatan kerja yang diperoleh akan semakin baik, karena pendidikan merupakan cerminan kualitas seseorang akan suatu pekerjaan ketika memasuki dunia kerja. Begitu sebaliknya ketika pendidikan seseorang rendah, maka kesempatan kerja/peluang kerja yang dia peroleh akan semakin rendah, karena diiringi dengan rendahnya skill/kualitas kerja yang dimilikinya. Menurut Harsono (2011), pendidikan merupakan salah satu faktor yang penting dalam pengembangan sumber daya manusia (SDM), karena pendidikan tidak saja menambah pengetahuan, akan tetapi juga meningkatkan keterampilan bekerja, dengan demikian meningkatkan produktivitas kerja.

Pengaruh UMR dan Pendidikan Terhadap Kesempatan Kerja dan Pertumbuhan Ekonomi Kabupaten/Kota

Provinsi Bali 
Menurut penelitian Wijaya dkk., (2014); Atiyatna dkk., (2016); Ganie (2017) yang menyatakan bahwa pendidikan berpengaruh positif dan signifikan terhadap penyerapan tenaga kerja. Hal tersebut dikarenakan bahwa semakin berpendidikan seorang pekerja maka kemampuan dalam menjalankan kegiatan operasional usaha akan semakin baik, sehingga hal tersebut yang akan dapat mendorong kemampuan produksi suatu usaha yang semakin meningkat dan akan berdampak bagi semakin baiknya kemajuan usaha tersebut dimasa depan dalam membuka akses penyerapan tenaga kerja dan mendukung peningkatan pertumbuhan ekonomi wilayah.

Berdasarkan hasil analisis diperoleh standardized coefficients Beta sebesar -0,713 dengan nilai signifkansi $0,000<\alpha=0,05$ diketahui bahwa UMR berpengaruh negatif dan signifikan terhadap pertumbuhan ekonomi di Kabupaten dan Kota Provinsi Bali. Artinya bahwa ketika UMR mengalami penurunan maka akan berpengaruh terhadap peningkatan pertumbuhan ekonomi. UMR adalah besaran upah yang diterima oleh pekerja, jadi UMR yang rendah tersebut berdampak terhadap semakin banyaknya kesempatan kerja yang dibuka oleh perusahaan atau pelaku usaha untuk memaksimalkan produksinya, hal tersebut dikarenakan kesempatan bagi pelaku usaha untuk dapat membayar upah pekerja yang tidak terlalu tinggi, sehingga hal tersebut dapat menstimulus pergerakan ekonomi karena akan semakin besar perputaran uang dimasyarakat dan tingginya minat beli masyarakat karena harga produk dapat menjadi lebih terjangkau, sehingga dapat terus mendorong produksi suatu usaha dan mendorong konsumsi, serta tumbuhnya perekonomian wilayah. Namun sebaliknya dalam hal ini ketika jumlah UMR mengalami peningkatan namun tidak diiringi dengan peningkatan produktivitas pekerja dalam menghasilkan produksi yang berdampak terhadap stagnannya penjualan bahkan mengalami penurunan, maka akan berdampak negatif terhadap pertumbuhan ekonomi wilayah.

Menurut penelitian Iswara dkk.,(2016) yang menyatakan bahwa upah minimum regional berpengaruh negatif dan signifikan terhadap pertumbuhan ekonomi wilayah. Hal tersebut dikarenakan bahwa ketika terjadinya peningkatan UMR namun tidak diiringi dengan produktivitas pekerja, maka hal tersebut akan cenderung menjadi permasalahan bagi perusahaan untuk mengurangi pekerjanya dan akan berdampak bagi ketidakstabilan pertumbuhan ekonomi wilayah karena akan banyak timbul pengangguran dan kemiskinan baru pada wilayah. Hal senada juga diungkapkan oleh penelitian Kertiasih (2017) yang menyatakan bahwa UMR berpengaruh negatif signifikan terhadap pertumbuhan ekonomi wilayah. Hal tersebut dikarenakan bahwa ketika UMR yang diterima oleh pekerja terkadang tidak mencerminkan kondisi upah riil yang diterima oleh pekerja, sehingga mereka terpaksa harus menurunkan daya beli yang pada akhirnya akan berdampak terhadap lemahnya penjualan usaha/aktivitas ekonomi dan akan berdampak terhadap penurunan pertumbuhan ekonomi wilayah.

Berdasarkan hasil analisis diperoleh standardized coefficients Beta sebesar 0,461 dengan nilai signifkansi $0,000<\alpha=0,05$ diketahui bahwa pendidikan berpengaruh positif dan signifikan 
terhadap pertumbuhan ekonomi di Kabupaten dan Kota Provinsi Bali. Hal tersebut berarti bahwa semakin tinggi tingkat pendidikan penduduk pada suatu wilayah maka hal tersebut dapat mendorong peningkatan pertumbuhan ekonomi wilayahnya. Hal tersebut dikarena bahwa pendidikan merupakan suatu bentuk pemahaman akan ilmu pengetahuan hard skill dan soft skill seseorang, jadi semakin berpendidikan seseorang maka orang tersebut akan semakin dapat memanfaatkan peluang-peluang ekonomi menjadi suatu bentuk usaha atau mampu mencari pekerjaan yang baik untuk merubah status ekonomi hidupnya, jadi semakin banyak suatu usaha dan pekerja professional pada suatu wilayah maka akan mendorong kemajuan bisnis dan usaha diwilayah tersebut dan berdampak bagi peningkatan pertumbuhan ekonomi wilayah yang semakin maju dan merata.

Menurut penelitian Nugroho (2014) dan Yuhendri dkk., (2013), yang menyatakan bahwa pendidikan berpengaruh signifikan terhadap pertumbuhan ekonomi, hal tersebut karena pendidikan yang tinggi akan berimplikasi terhadap hidup manusia yang semakin berkualitas. Dalam kaitannya dengan perekonomian, semakin tinggi kualitas hidup suatu wilayah, maka akan semakin tinggi tingkat pertumbuhan dan kesejahteraan masyarakat diwilayah tersebut, makin dengan tingginya tingkat pendidikan tenaga kerja maka akan semakin tinggi produktivitasnya dan dengan demikian juga akan makin tinggi pertumbuhan ekonomi wilayah dalam mewujudkan pemerataan dan keadilan bagi masyarakat.

Berdasarkan hasil analisis diperoleh standardized coefficients Beta sebesar 0,258 dengan nilai signifkansi $0,033<\alpha=0,05$ dapat diketahui bahwa kesempatan kerja berpengaruh positif dan signifikan terhadap pertumbuhan ekonomi Kabupaten dan Kota di Provinsi Bali. Hal tersebut berarti bahwa semakin besar peluang kesempatan kerja yang tersedia pada suatu wilayah, berarti menunjukkan perkembangan ekonomi wilayah tersebut semakin maju, sehingga apabila hal tersebut dapat berjalan secara berkelanjutan maka akan dapat mendorong peningkatan pertumbuhan ekonomi wilayah, dapat menekan angka pengangguran, kemiskinan dan kriminalitas.

Menurut penelitian Mariana dkk., (2014) dan Nurohhman \& Arifin (2010) yang menyatakan bahwa kesempatan kerja berpengaruh positif dan signifikan terhadap pertumbuhan ekonomi wilayah. Semakin baik kondisi ekonomi suatu wilayah menandakan bahwa keberlangsungan aktivitas produktif pekerja dan masyarakat berjalan dengan stabil, apabila jumlah pekerja yang telah terserap didunia kerja dan dapat menghasilkan produktivitas yang maksimal maka hal tersebut dapat mendorong peningkatan pendapatan usaha yang nantinya akan berdampak juga terhadap pertumbuhan ekonomi wilayah serta penyerapan tenaga kerja. Proses tersebut akan berdampak baik terhadap pemerataan kemajuan pembangunan wilayah dalam menekan angka pengangguran dan ketimpangan diwilayah tersebut.

Pengaruh UMR dan Pendidikan Terhadap Kesempatan Kerja dan Pertumbuhan Ekonomi Kabupaten/Kota 
Berdasarkan hasil perhitungan diperoleh $Z_{\text {hitung }}$ sebesar -0,054, di mana $\left|Z_{\text {hitung }}\right|<Z_{\text {tabel }}=$ 1,96, maka Ho diterima. Artinya bahwa kesempatan kerja bukan merupakan variabel mediasi pengaruh UMR terhadap pertumbuhan ekonomi di Provinsi Bali. Hal tersebut berarti bahwa meningkatnya kesempatan kerja pada suatu wilayah tidak berpengaruh terhadap peningkatan UMR dan juga pertumbuhan ekonomi wilayah. Hal tersebut dikarenakan bahwa kesempatan kerja yang meningkat cenderung biasanya diiringi dengan rendahnya UMR pada suatu wilayah untuk mengejar batas produksi suatu usaha yang maksimal dengan jumlah pekerja yang banyak, namun hal tersebut dapat meningkatkan pertumbuhan ekonomi wilayah apabila hasil produksi tersebut dapat meningkatkan pendapatan, namun biasanya kesempatan kerja yang terbatas adalah efek dari tingginya ekonomi wilayah, sehingga cenderung suatu usaha akan mempekerjakan pekerja dalam jumlah yang sedikit dan lebih mengoptimalkan penggunaan faktor produksi yang lainnya dalam memaksimalkan usahanya dan menekan biaya produksi.

Berdasarkan hasil perhitungan diperoleh $Z_{\text {hitung }}$ sebesar 1,98, di mana $\left|Z_{\text {hitung }}\right|>Z_{\text {tabel }}=$ 1,96, maka Ho ditolak. Artinya kesempatan kerja merupakan variabel mediasi pengaruh pendidikan terhadap petumbuhan ekonomi di Provinsi Bali. Artinya bahwa apabila tingkat pendidikan seseorang meningkat maka secara otomatis akan diiringi dengan meningkatnya pemahaman/pengetahuan seseorang untuk lebih siap bersaing didunia kerja, sehingga hal tersebut akan dapat mendorong semakin meningkatnya jumlah kesempatan kerja yang ada dan mendorong maksimalnya kinerja usaha dalam mendukung peningkatan produksi dan pendapatan serta akan berdampak bagi peningkatan pertumbuhan ekonomi wilayah.

Tabel 7.

Pengaruh Langsung, Pengaruh Tidak Langsung dan Pengaruh Total Variabel

\begin{tabular}{cccc}
\hline & \multicolumn{2}{c}{ Pengaruh } & Total \\
\cline { 2 - 4 } Hubungan Variabel & Langsung & $\begin{array}{c}\text { Tidak Langsung } \\
\text { Melalui Y1 }\end{array}$ & \\
\cline { 2 - 4 } $\mathrm{X}_{1} \longrightarrow \mathrm{Y}_{1}$ & -0.007 & & -0.007 \\
$\mathrm{X}_{2} \longrightarrow \mathrm{Y}_{1}$ & 0.595 & & 0.595 \\
$\mathrm{X}_{1} \longrightarrow \mathrm{Y}_{2}$ & -0.713 & -0.002 & -0.715 \\
$\mathrm{X}_{2} \longrightarrow \mathrm{Y}_{2}$ & 0.461 & 0.154 & 0.615 \\
$\mathrm{Y}_{1} \longrightarrow \mathrm{Y}_{2}$ & 0.258 & & 0.258 \\
\hline
\end{tabular}

Sumber: data diolah, 2020

Pengaruh UMR dan Pendidikan Terhadap Kesempatan Kerja dan Pertumbuhan Ekonomi Kabupaten/Kota

Provinsi Bali 


\section{SIMPULAN DAN SARAN}

Berdasarkan hasil pembahasan penelitian tersebut, maka kesimpulan yang dapat diberikan sebagai berikut. UMR tidak berpengaruh terhadap kesempatan kerja di Kabupaten dan Kota Provinsi Bali, sedangkan pendidikan berpengaruh positif dan signifikan terhadap kesempatan kerja di kabupaten/kota di Provinsi Bali. UMR berpengaruh negatif dan signifikan terhadap pertumbuhan ekonomi di Kabupaten dan Kota di Provinsi Bali, sedangkan pendidikan dan kesempatan kerja berpengaruh positif dan signifikan terhadap pertumbuhan ekonomi di Kabupaten dan Kota di Provinsi Bali. Kesempatan kerja tidak memediasi pengaruh UMR terhadap pertumbuhan ekonomi di Kabupaten dan Kota di Provinsi Bali, sedangkan kesempatan kerja memediasi pengaruh pendidikan terhadap pertumbuhan ekonomi di Kabupaten dan Kota di Provinsi Bali.

Saran yang dapat diberikan sebagai berikut, Pemerintah pusat maupun daerah di Provinsi Bali harus memperhatikan penetapan UMR yang terjadi, dengan memperhatikan inflasi yang terjadi dalam kurun waktu belakangan ini, agar penetapan upah yang dilakukan pemerintah tidak mempengaruhi peningkatan biaya output yang harus dikeluarkan oleh suatu perusahaan. Hendaknya bagi investor yang ingin berinvestasi di suatu daerah diberikan kemudahan dan keringanan biaya untuk berinvestasi, serta keringanan pajak yang ditanggung, sehingga investor tetap mau menanamkan modalnya di daerah tersebut. Hal ini akan berdampak pada pemerataan pendapatan di masing-masing daerah.

\section{REFERENSI}

Ade Jamal mirdad, dan Rizky Trinanda Akhbar. 2015. Analisis Elastisitas Kesempatan Kerja Pada Sektor Industri Pengolahan di Provinsi Jawa Barat. Jurnal Riset Ekonomi Pembangunan. 3(1), 249-262.

Aleksandra Majchrowska, Zbigniew Zółkiewski. 2014. The Impact of Minimum Wage on Employment in Poland. International Journal of Investigaciones Regionales. 2(4),211-239.

Alexandra Hukom. 2014. Hubungan Ketenagakerjaan Dan Perubahan Struktur Ekonomi terhadap Kesejahteraan Masyarakat. Jurnal Ekonomi Kuantitatif Terapan. 7(2),120-129.

Dian Purnama Yanthi, Cokorda Istri., Marhaeni., A.A.I.N. 2015. Pengaruh Pendidikan, Tingkat Upah dan Pengangguran Terhadap Persentase Penduduk Miskin di Kabupaten/Kota Provinsi Bali. Jurnal Piramida. 11(2), 68-75.

Emilia Herman. 2015. The Impact of Economic Growth Process on Employment in European Union Countries. The Romanian Economic Journal. 1(4), 47-67.

Erick Permana Saputra. 2016. Pengaruh Pertambahan Penduduk dan Dampaknya Terhadap Kesempatan Kerja di Kota Bontang. Jurnal Ilmu Pemerintahan. 4(3), 961-970.

Gideon Kiguru Thuku, Gachanja Paul and Obere Almadi. 2013. The Impact of Population Change on Economic Growth In Kenya. International Journal of Economics and Management Sciences. 2(6), 43-60.

Hung Wong, Shengquan Ye. 2014. Impact of enforcing a statutory minimum wage on work and quality of life of vulnerable groups in Hong Kong. International Journal of Social Welfare. 3(7), 1-13.

Izatun Purnami. 2015. Pengaruh Tingkat Pendidikan dan Upah Minimun Kabupaten/Kota terhadap Penyerapan Tenaga Kerja di Provinsi Jawa Barat Tahun 2010-2013. Jurnal Ekonomi dan Bisnis. 1(4), 1-16.

Pengaruh UMR dan Pendidikan Terhadap Kesempatan Kerja dan Pertumbuhan Ekonomi Kabupaten/Kota Provinsi Bali 
Keiko Tamada. 2015. Analysis of the Determinants of Minimum Wages in Japan. Journal International of Japan Labor Review. 8(2), 24-41.

Kiran.R, Subashini K, K.Nagamani. 2014. Impact of Economic Growth on Employment in India. International Journal of Innovative Research in Science, Engineering and Technology. 3(4), 2319-8753.

Mantra, Ida Bagus. 2009. Autobiografi Seorang Budayawan. Penyunting I.B. Wiana. Upada Sastra, Denpasar

Mudrajad, Kuncoro. 2013. "Metode Riset untuk Bisnis dan Ekonomi” Edisi 4. Jakarta: Erlangga.

Oka Artana Yasa, I Komang, Sudarsana Arka. 2015. Pengaruh Pertumbuhan Ekonomi dan Disparitas Pendapatan Antar daerah Terhadap Kesejahteraan Masyarakat Provinsi Bali. Jurnal Ekonomi Kuantitif Terapan. 8(1), 63-71.

Patricia Jones. 2017. The Impact of Minimum Wage Legislation in Developing Countries where Coverage is Incomplete. International Journal of African Economies. 2(9), 1-29.

Richard P. Cincotta and Robert Engelman. 2017. Economics and Rapid Change: The Influence of Population Growth. International Journal of Population Action International. 3(5), 130.

Saltiel, F. Urzúa, S. 2017. The Efefct of The Minimum Wage on Employment in Brazil. International Journal of Economic. 2(4), 2-12.

Samuel Randy Tapparan. 2017. Pengaruh Upah Minimum dan Investasi terhadap Kesempatan Kerja di Provinsi Sulawesi Selatan. Jurnal Administrasi. 4(1), 1-8.

Simanjuntak, Payaman J. 2015. Pengantar Ekonomi Sumber Daya Manusia. Jakarta : Fakultas Ekonomi Universitas Indonesia.

Siti Nur Aishah Mohd Hashim. 2016. Minimum Wage Policy Effects on Economic Growth. International Journal of Economics and Management Sciences. 4(9): h: 1-21.

Suartha, Nyoman, Murjana Yasa., I Gst Wayan., 2017. Pertumbuhan Penduduk dan Alih Fungsi bangunan Penduduk Asli Kota Denpasar. Jurnal Ekonomi Kuantitif Terapan. 10(1), 95-107

Sugiyono, 2010. Metode Penelitian Bisnis. Cetakan Ke-15. Bandung: Alfabeta.

Sukirno, Sadono. 2007. Makro Ekonomi Modern. Jakarta :Rajawali Pers.

Suyana Utama. 2016. Buku Ajar Aplikasi Analisis Kuantitatif. Denpasar: CV. Sastra Utama.

Vivi Alatas, Lisa Cameron. 2016. The Impact of Minimum Wages on Employment in a Low Income Country: An Evaluation using the Difference-in-Differences Approach. International Journal of Economics University of Melbourne. 4(3), 1-43

Ximena Del Carpio, Cuong Nguyen, Ha Nguyen, Choon Wang. 2013. The Impact of Minimum Wages on Employment, Wages and Welfare: The Case of Vietnam. International Journal of Munich Personal Repec Archive. 1(8), 1-32

\footnotetext{
Pengaruh UMR dan Pendidikan Terhadap Kesempatan Kerja dan Pertumbuhan Ekonomi Kabupaten/Kota Provinsi Bali 